Pakistan Journal of Humanities and Social Sciences

July - September 2018, Volume 6, No. 3, Pages 315 - 324

\title{
The Relationship of Market Orientation and Entrepreneurial Orientation WITHSME'S Performance in the Context of Pakistan
}

\author{
Muhammad Hassan Arshad ${ }^{1}$, Maha Mohammad Yusr Othman ${ }^{2}$, \\ Maruf Gbadebo Salimon ${ }^{3}$ \\ ${ }^{1,2 \& 3}$ School of Business Management, Universiti Utara Malaysia, Malaysia \\ Email: hasanarshad29@gmail.com
}

\begin{abstract}
The small and medium-sized enterprises (SMEs) plays a crucial part in country's economic growth and a key contributor in country's GDP. In Pakistan SMEs hold about 90 percent of the total business. The performance of SMEs depends upon many factors. The main purpose of this research is to examine the relationship between Entrepreneurial Orientation and Market Orientation with SME's Performance in Pakistan Conclusively, this study proposes a new research direction and proposition development to inspect the relationship among the variables in Pakistan's SMEs context.
\end{abstract}

Keywords: $\quad$ Market Orientation, Entrepreneurial Orientation and Performance of SMEs

\section{Introduction}

SMEs are considered as one of the main pillars in country's economic growth and a key contributor in country's GDP. In the emerging economies, SMEs are the major contributor to the national economic development and also a major source of the employment generation (Irfan, Kee, Qureshi\& Hussain, 2014). Generally It is a viewed that the large firm contributes more to the economic development and foreign exchange earnings, but now this point of view has been changed because countries like Japan, Korea, and Taiwan has developed their economies by Small and Medium Enterprises businesses (Anwar Ali Shah, Tariq Mehmood, Muhammad Aamir Hashmi, Syed Maqsood Shah, \& Faiz Muhammad Shaikh, 2011). The role of SME's cannot be neglected in the current challenging business environment. SME's are the main source to create employment opportunities (Acs and Audretsch, 1990; Brock and Evans, 1986).

In the case developing nations, the role of SMEs is considered more emphatic because this sector is regarded as a vital means of boosting the development of the country as much as or even more than Multinational Large enterprises (MNEs). Iftikhar Hussain, Steven Si, X.M. Xie, Lixia Wang (2010) highlighted that SMEs contributes in variety of ways which 
are of immense benefits to the economy, for example, creating jobs which result in low cost of capital. More so, the SMEs elasticity and flexibility structure is another advantage possessed over large firms.

Arinaitwe, (2006) stated that, Despite generous contribution and economic support towards development, it is acknowledged that SMEs performance remains below the expectation level among developing countries. The lower level of SMEs performance, contributing factors comprises of critical economic conditions, poor infrastructure support, inconsistent public policies, financial constraints, high operating cost and corruption (Ogbo \& Nwachukwu, 2012). Researcher, scholar, and practitioners underlined well about the significance and importance of SMEs, but still some studies argued some significant weaknesses that exist with SMEs and their performance relationship. Various studies indented many constraints and barriers for the SMEs performance (Muzaffar Hussain Shah, Abdul Rahim B Othman, \& Mohd Naqid Bin Mansor, 2016).

There is no doubt that SMEs are the key contributor towards the economic development of each country. However, the SMEs collapse ratio is still very high and alarming situation for developing, emerging as well as developed countries. Past studies acknowledged that within the five years of the business operation, significant numbers of new SMEs fails in this duration (Kuratko, 2005; Mbonyane \& Ladzani, 2011). Several studies from Australia, USA and England exposed that approximately $80 \%$ to $90 \%$ failure of SMEs within 5-10 years (Ghobakhloo, Hong, Sabouri, \& Zulkifli, 2012; Kuratko, 2005). However, the Pakistani SMEs failure rate is approximately $90-95 \%$ in the initial stages (Ullah, Dean \& Kaleem, 2011).

In the past decade, evidence showed that performance of Pakistani SMEs is quite dismal. The main factors that contribute towards the poor performance are low level of productivity, less innovation, poor $\mathrm{R} \& \mathrm{D}$, unskilled labor force, and competitiveness that are the main obstacles for the firms in creating and sustaining competitive advantage (Tanveer, Rizvi \&Riaz, 2012).

\section{Literature Review}

\section{A. SMEs Performance}

Organizations are commonly defined as instruments of creating value for the purpose of its products and services amongst the customers. Organizations compete with one another, to seek competitive advantage and superior performance (March \& Sutton, 1997). Performance has been the most vital concern for every organization, to be it profit or non- 
profit one (Yusr, Othman, 2016). It is very important for the owners or managers to identify the factors which affect the performance in order to make them competitive and profitable (Abu-Jarad, Yusof \& Nikbin, 2010). Different scholars have conceptualized and measured performance in different ways. Researchers have put forth different opinions, approaches and definitions of performance.

Performance is a major concern for firms that want to remain in business and thus accomplish its goals. Some researchers try to examine how to improve the company's performance and some study firm performance predictors (Mahmood \& Hanafi, 2013).

Ireland, Hitt, and Sirmon, (2003) revealed that the concept of performance measurement is highly misunderstood and misconceived by SMEs which usually fail to envision the potential merits of developing and implementing a performance measurement program. It was further added that SMEs perceive the implementation of performance measurement programs as a step forward towards bureaucratization and to limit the extent of flexibility in SMEs (Hvolby \& Thorstenson, 2000).

\section{B. Market Orientation}

Market orientation (MO) is a firm's philosophy to cater the customer's needs in the best possible means (Narver \& Slater, 1990). Hunt and Morgan (1995) viewed MO as a resource and a basis for decision making. Past literature showed that empirical studies on MO started during early 1990s and has been known as an important business approach for SMEs as well as for large businesses.

Kotler, Armstrong and Cunningham (2005) explored that market-oriented firms always tend to stay close to their customers to discover their needs and to create value for the firms in terms of profitability and market share. Market-oriented businesses seek for the ways to develop superior solutions to fulfill the potential needs of customers (Day, 1994). Besides that, MO focuses on bringing innovation in product, process and improves the firm performance (Zhou, Gao, Yang \& Zhou 2005). Furthermore, Narver, Slater and Tietje (1998) observed that market oriented firms assign resources more efficiently and able to focus on customer's requirements.

Laukkanen et al. (2013) stated that that MO emphasizes in to create superior customer value and also focus in the interest of stakeholders. More overly focus on to gather market information and act proactively.

In the past literature, various researchers showed a significant relationship between market orientation and performance, which are; Amir khani and Fard (2009), Aziz and Yasin 
(2010). However, few studies reported non-significant relationship between market orientation and firm performance, such as Han et al, (1998), Pelham, (1997).Due to inconsistent results, there is a need for further study.

\section{Entrepreneurial Orientation}

Entrepreneurship is a French word which means to start to act. Entrepreneurship happens when a person has some idea, resources and dedication to work upon it to flourish the business which can result in developing new organization or restructuring the existing firm to avail future opportunities. The initial form of entrepreneurship can be visible when a new business starts up. As the concept of entrepreneurship establishes in 1930s, due to researches various concepts has been originated (Katsikis \& Kyrgidou, 2009).

Miller and Friesen (1983) proposed the concept of EO and later on different scholars establishes further definitions of EO. Entrepreneurial orientation can be defined as the capability of the organization to determine and utilize the innovative ideas to attain the new market and establish the business to gain competitive advantage. Various decision making styles can implement such as proactive approach and risk taking so the directors can act as entrepreneur's (Lumpkin \& Dess, 1996).

EO is an important strategic construct aimed to enhance the performance of a firm (Covin et al., (2006). It is used in the field of entrepreneurship to measure firm capability to innovate, bring change in its processes and improve the performance. It is significant to note that many scholars i.e. Guth and Ginsberg (1990) and Dess, Lumpkin and Covin (1997) have given considerable importance to EO in improving the performance of large businesses and SMEs. Study of the past literature illustrated that lot of studies on EO and performance were conducted on large scale organizations, but very few have emphasized their study on the link between EO and SMEs performance specifically in the perspective of developing nations.

However, the extent of the relationship to link EO and performance seems to be differing across different research studies. Some studies, i.e. Covin and Slevin (1986); Lee, Lee and Pennings (2001) have found that EO strongly and significantly impact on performance and confirmed the notion that entrepreneurial firms perform much better than non-entrepreneurial firms. However, (Walter et al. 2006) stated non-significant relation between EO and performance. The limited positive relationship has been found between entrepreneurial orientation and firm performance (Swierczek and Ha, 2003).More overly, various other researchers's also highlighted lesser influence of EO on performance.

Based on the literature review following propositions are proposed: 
P1: Market orientation has a significant effect on performance of SMEs

P2: Entrepreneurial orientation has a significant effect on performance of SMEs

\section{Proposed Conceptual Framework}

According to the resource-based view, strategic orientations i.e. market orientation and entrepreneurial orientation is a pool of internal resources that can establish a competitive edge (Barney, 1991). So, these strategies are rare and important for the firms in order to be competitive in the market. The RBV is considered as one of the most phenomenal theoretical perspective in the strategic management literature (Barney, 1991; Helfat \& Raubitschek, 2000).

The ability of a firm to recognize, develop, employ and maintain specific resources and differentiate them from its rivals, facilitate and assist its success to sustain competitive advantage (Carmeli \& Tishler, 2004). Barney (1991) suggested that firm has to possess the important and key tangible and intangible resources and strategic capabilities that are important, extraordinary, costly to imitate and non-substitutable. RBV was first introduced by Wernerfelt (1984) and has been seen as the best research area for the last few years (Galbreath, 2005). According to Wernerfelt (1984) organizational success is determined by internal resources and capabilities, such as knowledge and accumulated skills to create superior firm performance and value.

Therefore, this study checked the relationship of MO and EO with performance which is in line with the RBV. Comprehensive literature review showed that MO and EO are considered as the capabilities that create the competitive edge. As argued by Reed, Lemak and Mero (2000) MO is one of the main resources of competitive advantage, while, Weerawardena and Coote (2001) considered EO another source of competitive advantage. Moreover, $\mathrm{MO}$ is also one of the strategic orientations that create superior performance (Narver \& Slater, 1990).

\section{Conclusion and Recommendation}

SMEs are considered as the backbone for the progress and growth of economy of the country. Pakistan is a developing country, facing economic instability and due to high population, the unemployment rate is also increasing. SMEs are considered as an effective source to steer forward the economy and generate employment opportunities in the country. But due to weak management system, untrained and unskillful labor force, lack of capital and limited infrastructure facilities available to them, SMEs in Pakistan are exhibiting poor performance. 
Entrepreneurial orientation and market orientation are widely recognized as important management strategies meant to improve the performance of organizations. Within the premise of RBV theory, that strategies must be aligned, this study done to examine the impact of $\mathrm{EO}$ and $\mathrm{MO}$ on firm performance.

The study suggests that policy makers and practitioners should not be dependent on a particular management technique but multiple management strategies aligned with external environment should be employed for better survival and success of SMEs. Finally, the theoretical model of this study was developed from relevant current and past literature which covers the key variables such as EO, MO and performance. This study provided new empirical contribution to the body of knowledge by synchronizing and relating the variables i.e., $\mathrm{MO}$ and performance in the theoretical model with underpinning theory - RBV. 
Pakistan Journal of Humanities and Social Sciences, 6(3), 2018

\section{References}

Abu-Jarad, I. Y., Yusof, N., \&Nikbin, D. (2010).A review paper on organizational culture and organizational performance. International Journal of Business and Social Science, $1(3), 26-46$.

Acs, Z. J., \&Audretsch, D. B. (1990). Innovation and small firms.Mit Press.

Alpkan, L., Yilmaz, C. and Kaya, N. (2007), "Market orientation and planning flexibility in SMEs: performance implications and an empirical investigation”, International Small Business Journal, Vol. 25 No. 2, pp. 152-72.

Amirkhani, A. and Fard, R. S. (2009).The Effect of Market Orientation on Business Performance of the Companies Designing and Manufacturing Clean Rooms.American Journal of Applied Sciences. 6(7), 1373-1379.

Arinaitwe, S. K. (2006). Factors constraining the growth and survival of small scale businesses.A developing countries analysis. Journal of American Academy of Business, Cambridge, 8(2), 167-178.

Aziz, N. A., \&Yasin, N. M. (2010). How will market orientation and external environment influence the performance among SMEs in the agri-food sector in Malaysia?. International Business Research, 3(3), 154.

Barney, J. (1991). Firm resources and sustained competitive advantage. Journal of management, 17(1), 99-120.

Brock, W. and Evans, D. (1986), The Economics of Small Business: Their Roles and Regulations in US Economy, Holmes \& Meier Publishers, Teaneck, NJ.

Carmeli, A., \&Tishler, A. (2004).The relationships between intangible organizational elements and organizational performance. Strategic management journal, 25(13), 1257-1278.

Covin, J. G., \&Slevin, D. P. (1986). The development and testing of an organizational-level entrepreneurship scale. Frontiers of entrepreneurship research, 1(3), 628-639.

Covin, J. G., Green, K. M., \&Slevin, D. P. (2006). Strategic process effects on the entrepreneurial orientation-sales growth rate relationship. Entrepreneurship theory and practice, $30(1), 57-81$.

Day, G. S. (1994). The capabilities of market-driven organizations. Journal of Marketing, 58(4), 37-52. 
Dess, G.G., Lumpkin, G.T., Covin, J.G., 1997. Entrepreneurial strategy making and firm performance: tests of contingency and configurational models. Strategic Manage. J. 18 (9), $677-695$.

Galbreath, J. (2005). Which resources matter the most to firm success? An exploratory study of resource-based theory. Technovation, 25(9), 979-987.

Ghobakhloo, M., Hong, T. S., Sabouri, M. S., \&Zulkifli, N. (2012). Strategies for successful information technology adoption in small and medium-sized enterprises. Information, 3(1), 36-67.

Guth, W.A. and Ginsberg, A. (1990). Guest Editors' Introduction: Corporate Entrepreneurship. Strategic Management Journal, Vol.11: 5-15.

Han, Jin, Kim, Namwoon and Srivastava, Rajendra (1998). Market Orientation and Organizational Performance: Is Innovation a Missing Link? Journal of Marketing 62(4):30-45.

Helfat, C. E., \&Raubitschek, R. S. (2000). Product sequencing: co-evolution of knowledge, capabilities and products. Strategic management journal, 961-979.

Hunt, S. D., \& Morgan, R. M. (1995). The comparative advantage theory of competition. The Journal of Marketing, 1-15.

Hussain, I., Si, S., Xie, X. M., \& Wang, L. (2010). Comparative study on impact of internal and external CFFs on SMEs. Journal of Small Business \& Entrepreneurship, 23(4), 637-648.

Hvolby, H. H., \&Thorstenson, A. (2000).Performance measurement in small and mediumsized enterprises.In The Third SMESME International Conference, Coventry, UK.

Ireland, R. D., Hitt, M. A., \&Sirmon, D. G. (2003). A model of strategic entrepreneurship: The construct and its dimensions. Journal of management, 29(6), 963-989.

Irfan, S. M., Kee, D. M. H., Qureshi, R. W., \&Hussain, R. (2014). Measuring performance of SMEs in Pakistan using PLS-SEM: Evaluating MBNQA criteria as TQM framework. Science International, 26(4), 1707-1718.

Katsikis, I. and Kyrgidou, L. (2009), "Entrepreneurship in teleology: The variety of the forms", International Journal of Entrepreneurial Behavior \& Research, Vol. 15 No. 2 , pp. 209-231.

Kotler, P., Armstrong, G. and Cunningham, P. H. (2005). Principles of marketing (6th ed.). Toronto: Pearson Education Canada. 
Pakistan Journal of Humanities and Social Sciences, 6(3), 2018

Kuratko, D. F. (2005). The emergence of entrepreneurship education: Development, trends, and challenges. Entrepreneurship theory and practice, 29(5), 577-598.

Laukkanen, T., Nagy, G., Hirvonen, S., Reijonen, H., \&Pasanen, M. (2013). The effect of strategic orientations on business performance in SMEs: A multigroup analysis comparing Hungary and Finland. International Marketing Review, 30(6), 510-535.

Lee, C., Lee, K., \&Pennings, J. M. (2001). Internal capabilities, external networks, and performance: a study on technology-based ventures. Strategic management journal, 22(6-7), 615-640.

Lumpkin, G. T., \&Dess, G. G. (1996). Clarifying the entrepreneurial orientation construct and linking it to performance. Academy of management Review, 21(1), 135-172.

Mahmood, R., \&Hanafi, N. (2013). Entrepreneurial orientation and business performance of women-owned small and medium enterprises in Malaysia: Competitive advantage as a mediator. International Journal of Business and Social Science, 4(1).

March, J. G., \& Sutton, R. I. (1997).Crossroads — organizational performance as a dependent variable. Organization science, 8(6), 698-706.

Mbonyane, B., \&Ladzani, W. (2011).Factors that hinder the growth of small businesses in South African townships. European Business Review, 23(6), 550-560.

Miller.D..\& Friesen, P. 1983. Strategy-making and environment: The third link. Strategic Management Journal. 4: 221-235.

Narver, J. C., \& Slater, S. F. (1990).The effect of a market orientation on business profitability. The Journal of marketing, 20-35.

Narver, J. C., Slater, S. F., \&Tietje, B. (1998).Creating a market orientation. Journal of Market-Focused Management, 2(3), 241-255.

Ogbo, A., \&Nwachukwu, A.Ch. (2012). The Role of Entrepreneurship in Economic Development: the Nigerian Perspective. European Journal of Business and Management, 4(8), 95-105.

Pelham, A. M. (1997). Mediating Influences on the Relationsmp between Market Orientation and Profitability in Small Industrial Firms. Journal of Marketing Theory and Practice, 5(3), 55-76.

Reed, R., Lemak, D. J., \&Mero, N. P. (2000). Total quality management and sustainable competitive advantage. Journal of quality management, 5(1), 5-26. 
Shah, A. A., Mehmood, T., Hashmi, M. A., Shah, S. M., \& Shaikh, F. M. (2011).Performance of SMEs in Export Growth and Its Impact on Economy of Pakistan. International Journal of Business and Management, 6(7), 287.

Shah, M. H., Othman, A. R. B., \& bin Mansor, M. N. (2016). Moderating Role of Environmental Turbulence on the Relationship between Innovative Practice, Mentoring, Social Capital and Small Business Performance. Asian Journal Of Multidisciplinary Studies, 4(8) 1-12.

Slater, S. F., \&Narver, J. C. (2000). The positive effect of a market orientation on business profitability: a balanced replication. Journal of business research, 48(1), 69-73.

Swierczek, F. W., \& Ha, T. T. (2003). Entrepreneurial orientation, uncertainty avoidance and firm performance: an analysis of Thai and Vietnamese SMEs. The International Journal of Entrepreneurship and Innovation, 4(1), 46-58.

Tanveer, M. A., Rizvi, S., \&Riaz, W. (2012). Declining market share of Pakistan in football industry. Asian Journal of Business and Management Sciences, 1(11), 33-42.

Ullah, H., Dean, B. S., \&Kaleem, M. (2011). A study of owners' inherited factors affecting orientation in Khyber Pakhtunkhwa-Pakistan. Interdisciplinary Journal of Contemporary Research in Business, 3(1), 712-725.

Walter, A., Auer, M., \& Ritter, T. (2006).The impact of network capabilities and entrepreneurial orientation on university spin-off performance. Journal of business venturing, 21(4), 541-567.

Weerawardena, J., \&Coote, L. (2001).An empirical investigation into entrepreneurship and organizational innovation-based competitive strategy. Journal of Research in Marketing and Entrepreneurship, 3(1), 51-70.

Wernerfelt, B. (1984). A resource-based view of the firm. Strategic management journal, 5(2), 171-180.

Yusr, M. M. (2016). Innovation capability and its role in enhancing the relationship between TQM practices and innovation performance. Journal of Open Innovation: Technology, Market, and Complexity, 2(1), 6.

Zhou, K. Z., Gao, G. Y., Yang, Z., \& Zhou, N. (2005). Developing strategic orientation in China: Antecedents and consequences of market and innovation orientations. Journal of Business Research, 58(8), 1049-1058. 